\title{
Teachers, Sexual Orientation, and the Law in Canada: A Human Rights Perspective
}

\author{
ELIZABETH J. MEYER
}

\begin{abstract}
Teacher expression on the subject of sexual orientation is a hotly contested topic that has led to many recent legal challenges in the United States and Canada. The purpose of this article is to offer readers an introduction to Canadian cases regarding teacher expression and sexual orientation and demonstrate how the application of a human rights framework can offer schools and educators an ethically sound and legally defensible way of approaching and resolving such controversies.
\end{abstract}

$\mathbf{T}$ eacher expression on the topic of sexual orientation is a hotly contested issue that has led to many recent legal challenges in the United States and Canada. Schools lie at the center of the ongoing culture wars related to sexual orientation and religion, because they are responsible for preparing students to be active citizens in a democratic society (Meyer and Stader 2009). In the United States, the legal terrain for such cases is often murky, because sexual orientation is not explicitly included in most nondiscrimination policies and legislation, and likewise, sexual orientation is not considered a suspect or quasi-suspect class. However, in Canada, sexual orientation has federally protected status within the Canadian constitution, specifically in the Charter of Rights and Freedoms (1985), and, therefore, the legal issues are somewhat different. Most challenges in the United States and Canada pertaining to sexual orientation and education are linked to conflicts between freedom of expression and religious freedom: two essential human rights identified by the United Nations (United Nations 1948, Articles 18 and 19). The struggle to balance these competing claims has led to several important court challenges regarding teacher expression in and out of the classroom. A recent article in the American Educational Research Journal (Eckes and McCarthy 2008) presented an overview of such cases in the United States. The authors discuss these cases in the context of teachers' "lifestyle choices" (Eckes and McCarthy 2008, 533), rather than addressing sexual orientation as an essential aspect of teachers' identities, cultures, and family structures, which is somewhat problematic. By using phrases such as "pursue a GLBT [gay, lesbian, bisexual, transgendered] lifestyle" (Eckes and McCarthy 2008, 545), the authors imply that sexual orientation is a choice, rather than recognizing GLBT people as members of an identifiable social group that has been the target of systematic discrimination and oppression (Frye 1983). However, Eckes and McCarthy's article does offer a comprehensive overview of U.S. litigation involving GLBT educators, starting with Morrison v. Board of Education (1969) and continuing through Curcio v. Collingswood Board of Education (2006), as well as offering a snapshot of current statutes in seventeen states that ban discrimination of employees based on sexual orientation.

The purpose of this article is to offer readers an introduction to Canadian cases regarding teacher expression and sexual orientation, and to demonstrate how the application of a human rights framework can offer schools and educators an ethically sound and legally defensible way of approaching and resolving such controversies. The United Nations' Convention on the Rights of the Child (CRC; United Nations Children's Fund [UNICEF] 2009a) is an internationally recognized, legally binding agreement that identifies basic human rights for children. The United Nations Children's Fund (UNICEF) explains the human rights framework as follows,: "Human rights are those rights which are essential to live as human beings - basic standards without which people cannot survive and develop in dignity. They are inherent to the human person, inalienable and universal" (UNICEF 2009). The CRC was drafted in 1978 during the UN-sponsored International Year of the Child, but it was not adopted by the UN General Assembly until eleven years later, on November 20, 1989. Somalia and the United States are the only two UN countries who have not yet ratified this Convention. The two articles of the treaty that are most relevant to the discussion here are Article 2 on nondiscrimination and Article 28 on the right to education. Article 2 states: 
1 .States Parties shall respect and ensure the rights set forth in the present Convention to each child within their jurisdiction without discrimination of any kind, irrespective of the child's or his or her parent's or legal guardian's race, colour, sex, language, religion, political or other opinion, national, ethnic or social origin, property, disability, birth or other status.

1. States Parties shall take all appropriate measures to ensure that the child is protected against all forms of discrimination or punishment on the basis of the status, activities, expressed opinions, or beliefs of the child's parents, legal guardians, or family members. (UNICEF 2009a)

Article 28 addresses the right to education: "States Parties recognize the right of the child to education, and with a view to achieving this right progressively and on the basis of equal opportunity" (UNICEF 1989). Al though the UN's nondiscrimination statement does not specifically name sexual orientation, its clear position against discrimination in all of its forms - particularly as the discrimination relates to a child's access to education-is an important starting point for understanding how teachers should consider their speech and behavior regarding sexual orientation. Canada ratified the CRC in 1991 (Canadian Children's Rights Council, n.d.) and has a long history of working to address human rights issues at both the federal and provincial levels.

\section{The Canadian Context}

The current progressive political climate in Canada was achieved through a long and slow process of legislative reform that culminated in the adoption of the Canadian Charter of Rights and Freedoms (1985). This important document was incorporated into the Canadian constitution by the Constitution Act in 1982 (Watkinson 1999, 22). As part of the supreme law of Canada, this document supersedes all existing laws, and, for the first time, the right of all persons to be treated equally was given constitutional status. Although public education is primarily governed by provincial statutes, all publicly funded institutions must abide by the spirit and letter of the Charter (Watkinson 1999). This new constitution guarantees protections for many historically marginalized groups. Sexual orientation, however, was not initially included as a protected class for equality rights under Section 15 of the Charter. The original language of this section read:

Every individual is equal before and under the law and has the right to the equal protection and equal benefit of the law without discrimination and, in particular, without discrimination based on race, national or ethnic origin, colour, religion, sex, age or mental or physical disability. (Canadian Charter of Rights and Freedoms 1982)

Although the federal government was not willing to explicitly include the words "sexual orientation" in the Charter, other provinces had already established human rights codes that included this language. In 1977, the province of Quebec led the way in the equality movement for sexual minorities by adding "sexual orientation" to its Charter of Human Rights and Freedoms. Ontario followed suit nine years later. These charters were the first legal protections in Canada that clearly included sexual orientation as a protected class (Hurley 2005).

Although equality rights supported by the Charter were enforced starting in 1985, sexual orientation was not recognized as a protected class until ten years later, following a unanimous decision of the Supreme Court of Canada in the landmark case of Egan v. Canada (1995). Although this case did not address discrimination in schools, it addressed the issue of access to public services, and, specifically, the definition of "spouse" in the federal Old Age Security Act (Lahey 1999). Although the plaintiffs lost their case because the justices found that the particular discrimination was demonstrably justified, the ruling declared that discrimination based on sexual orientation was prohibited by Section 15 of the Charter. The justices wrote in their decision that "sexual orientation is a deeply personal characteristic that is either unchangeable or changeable only at unacceptable personal costs, and so falls within the ambit of s. 15 protection as being analogous to the enumerated grounds" (Egan v. Canada 1995, para. 5).

This case established the precedent to include sexual orientation as a protected class and read "sexual orientation" into the Charter. Every Canadian was now guaranteed the basic human right of equal protection from discrimination based on sexual orientation. Although some provinces, such as Alberta, were slow to add the term "sexual orientation" to their individual human rights codes, this protection was federally guaranteed as a result of this important ruling.

Since the Supreme Court's 1995 decision in Egan v. Canada, various cases have tested the interpretation and application of the equality rights extended in that case. Vriend v. Alberta (1998) was the first case concerning an educational institution after Egan. Delwin Vriend worked as a lab coordinator at King's College, a Christian university that had instituted a position statement condemning homosexuality and requiring all students and employees to comply with the university's position. Vriend was asked to resign when he confirmed that he was homosexual, but he refused and was fired. He initially brought forward a human rights complaint against King's College; however, his complaint was dismissed because the province of Alberta did not have sexual orientation listed as a protected class in its Human Rights, Citizenship and Multiculturalism Act. In this case, the Supreme Court stated that not protecting individuals from discrimination based on sexual orientation was an "unjustified violation of s. 15 of the Canadian Charter of Rights and Freedoms," and it ordered that the words "sexual orientation" be read into provincial human rights codes as a prohibited ground of discrimination (Vriend v. Alberta 1998, 2). This decision extended the 
interpretation in Egan to apply to teachers and other employees in educational institutions and began to establish parameters for balancing competing rights claims.

\section{Ross v. New Brunswick School District No. 15, 1996}

In the case of Ross v. New Brunswick School District No. 15 (1996), a board of inquiry found that a school board had discriminated against Jewish students by failing to take action against a teacher whose anti-Jewish writings and public statements outside the classroom were found to contribute to a poisoned environment within the classroom. The board of inquiry ordered the school board to terminate the teacher's employment even after he had been removed from the classroom, if at any time during his employment he had published or distributed anti-Jewish writings. This case is instructive and worth discussing in-depth, because it shows how Canadian courts have worked to balance competing rights claims while at the same time upholding human rights legislation that ensures "discrimination-free educational services" (Ross v. New Brunswick School District No. 15, 4).

On September 1, 1988, a human rights board of inquiry began investigating a complaint from a parent, Attis, who described himself as Jewish and stated that a teacher at his children's school, Ross, was making racist and discriminatory statements against Jews. Ross had distributed pamphlets, appeared on public television, and written letters that were published in local newspapers arguing that "Christian civilization was being undermined and destroyed by an international Jewish conspiracy" (Ross v. New Brunswick School District No. 15, 5). The board of inquiry found that the school board had failed to discipline Ross "meaningfully" and, by continuing his employment, had "endorsed his out-of-school activities and writings." This allowed a "poisoned environment" that "greatly interfered with the educational services provided" (Ross v. New Brunswick School District No. 15, 6). The board of inquiry ordered the school board to:

a) place Ross on leave of absence without pay for 18 months

b) appoint Ross to a non-teaching position if one became available during his leave of absence,

c) terminate his employment after eighteen months if he had not been offered and accepted a non-teaching position, and

d) terminate Ross immediately if he continued to publish his anti-Jewish views (Ross v. New Brunswick School District No. $15,6-7)$.

After the board of inquiry instituted this order, Ross applied for judicial review. The Court of Queen's Bench quashed the gag order $(d)$ on the grounds that it violated the teacher's freedoms of expression and religion under the Charter. The order removing the teacher from the classroom was upheld. This decision was made by applying the Oakes test, developed by Chief Justice Dickson in R. v. Oakes (1986), which applies two steps of analysis to determine if limiting a person's Charter rights can be justified. The first step identifies whether the legislative objectives in question are pressing and substantial, and the second identifies whether the objective is proportional to its discriminatory effectthat is, is it rationally connected to the objective? (Lahey 1999) In the Ross case, Justice Creaghan concluded that (a), (b), and (c) were "reasonable limit[s] prescribed by law that can be demonstrably justified" (Ross v. New Brunswick School District No. 15, 8), but he did not uphold section (d), because it would place limits on Ross' speech when he was no longer a classroom teacher and therefore would place an unreasonable restriction on his rights to freedom of expression and freedom of religion.

Ross then appealed this decision to the Court of Appeal, in which Justice Hoyt decided that the order could not stand and ruled that removing Ross from the classroom violated his rights to freedom of expression and religion, and that the order could not be upheld under the Charter, because it was directed at activities outside the classroom.

Attis then appealed the lower court's decision to the Supreme Court of Canada, which decided that the board's order did infringe on the teacher's freedom of expression and freedom of religion, and stated the goal of achieving proper balance between individual rights and community needs. The Supreme Court decided that removing Ross from his teaching position (sections $a, b$, and $c$ of the original order) was a justifiable infringement on his freedom of expression and freedom of religion, because the removal was rationally connected to the objective of creating a discrimination-free learning environment. The Supreme Court's decision indicated that it was reasonable to anticipate a causal relationship between the teacher's out-of-classroom expressions and the poisoned educational environment. However, once Ross was removed from teaching, the gag order (section $d$ ) that restricted his expression was no longer justified. Justice LaForest concluded his opinion by stating that, "The continued employment of the respondent contributed to an invidiously discriminatory or 'poisoned' educational environment... this finding is necessarily linked to the finding that the respondent's statements are 'highly public' and that he is a notorious anti-Semite, as well as the supported view that public school teachers assume a position of influence and trust over their students and must be seen to be impartial and tolerant" (Ross v. New Brunswick School District No. 15, 42).

The decision rendered in this case outlines clear criteria and expectations for public school teachers in Canada, where provincial human rights codes and the Charter establish the right for students to access "discrimination-free 
educational services." The decision in the Ross case and the application of the Oakes test established the foundation for the rest of the cases that followed.

In a lower court decision, the British Columbia Supreme Court found in favor of TWU, stating that teachers could hold "sexist, racist or homophobic beliefs" (Trinity Western University v. British Columbia College of Teachers, 5). However, the court also made the following distinction:

Acting on those beliefs, however, is a very different matter. If a teacher in the public school system engages in discriminatory conduct, that teacher can be subject to disciplinary proceedings. Discriminatory conduct by a public school teacher when on duty should always be subject to disciplinary proceedings [and] disciplinary measures can still be taken when di scriminatory off-duty conduct poisons the school environment. (Trinity Western v. British Columbia College of Teachers 2001, 5)

Although the court sided with TWU and allowed the institution to continue mandating anti-homosexual beliefs in their future teachers, the judges made the important distinction between discriminatory behaviors and beliefs. At issue in this decision was the fact that BCCT had failed to produce evidence that any graduate of TWU had behaved in a discriminatory manner toward his or her students. In the absence of proof of a poisoned environment (as was demonstrated in the Ross case), the court ruled that although discriminatory behavior is not to be tolerated, BCCT could not regulate teachers' beliefs. Although TWU won the right to exercise full control over its teacher education program, the next landmark case, Kempling v. British Columbia College of Teachers (2004), shows the outcome when teachers who hold deep religious beliefs against homosexuality express those views publicly.

\section{Trinity Western University v. B.C. College of Teachers, 2001}

The next case of interest was decided in May 2001, when the Supreme Court of Canada heard a case brought forward by Trinity Western University (TWU), a private religious institution, against the British Columbia College of Teachers (BCCT). The dispute occurred when the professional teachers' organization in the province of British Columbia (BCCT) responded to a request from TWU for full responsibility over its teacher-training program, which, at the time, it shared with Simon Fraser University. TWU wanted more autonomy over its program to reflect its Christian worldview. The BCCT chose not to accredit this teacher education program, because it believed the institution was discriminating on the basis of sexual orientation in its demands on students. TWU required students to sign a statement that asserted they would "refrain from practices that are biblically condemned," including premarital sex, viewing pornography, and homosexuality - much like the King's College statement in Vriend (Trinity Western University v. British Columbia College of Teachers 2001, 4).

\section{Kempling v. British Columbia College of Teachers, 2004}

The delicate balance between freedom of religion and freedom of expression was highlighted again a few years later when a teacher was suspended for making public statements that were perceived as anti-homosexual in nature. In February 2004, a teacher and guidance counselor, Chris Kempling, was suspended by BCCT for one month for "conduct unbecoming" to a teacher, because he had written letters to the editor of the Quesnel Cariboo Observer that were considered defamatory of homosexuals (Kempling v. British Columbia College of Teachers 2004,). Examples of Kempling's statements include: "I refuse to be a false teacher saying that promiscuity is acceptable, perversion is normal, and immorality is simply "cultural diversity' of which we should be proud," and "Sexual orientations can be changed and the success rate for those who seek help is high. My hope is students who are confused over their sexual orientation will come to see me" (Kempling 2004, para. 4). Kempling appealed this decision to the British Columbia Supreme Court, but the court held that BCCT was within its jurisdiction to suspend him. The court's rationale for its decision was based on the "wrongful public linking of his professional position to the off-duty expression of personally held discriminatory views in order to lend credibility to those views" (Kempling v. British Columbia College of Teachers 2004, para. 114).

In June 2008, Kempling chose to leave the public school system to work for an independent Catholic school. This action allowed him to relinquish his BCCT certification and avoid further suspensions and reprimands for his actions (White 2008; Kempling 2008).

The previous cases have outlined how provincial human rights codes and the Charter of Rights and Freedoms establish the responsibility of publicly funded schools in Canada to create learning environments that are free from discrimination. The final case analyzed in this article demonstrates what happens when a school fails to provide such an environment, and how the application of the human rights codes may be instructive for schools in other countries working to resolve these conflicts in ethical and legally defensible ways.

\section{School District No. 44 (North Vancouver) v. Jubran, 2005}

Azmi Jubran was a student who was repeatedly harassed by his peers over a period of five years (1993-1998). Much of the harassment included anti-gay slurs and was combined with physical acts such as spitting, kicking in the hallways, and slamming Jubran into lockers (Williams 2005). Jubran repeatedly complained to school administrators, but the harassment continued. He finally took action against the school and filed a complaint with the British Columbia Human Rights Tribunal in June of 1996 for "discriminating against him regarding an accommodation, service or facility 
customarily available to the public because of his sexual orientation" (School District No. 44 [North Vancouver] v. Jubran 2005). The Human Rights Tribunal ruled in Jubran's favor and awarded $\$ 4,500$ in damages for injury to dignity, feelings, and self-respect. This decision was appealed to the Supreme Court of British Columbia, which quashed the Human Rights Tribunal's decision through its interpretation that the behavior in question fell outside of Section 8 of the British Columbia Human Rights Codes, which enumerate the classes of citizens protected from discrimination in accommodation, service, and facility. The judge in this decision concluded that the fact that Jubran "is not a homosexual and the students who attacked him did not believe he was a homosexual" meant that Jubran should not be accorded the protections offered by the code (School District No. 44 [North Vancouver] v. Jubran 2005). This decision was appealed to the Court of Appeal for British Columbia.

The issues before the Court of Appeal centered on two major questions: "Must a person who complains of discriminatory harassment on the basis of sexual ori entation actually be a homosexual or perceived by his harassers to be a homosexual? Is a School Board responsible where the conduct of students violates the Code?" (School District No. 44 [North Vancouver] v. Jubran 2005, note 19, para. 1). These two questions are central to understanding the scope of human rights codes and the related school board responsibilities to create nondiscriminatory learning environments. Furthermore, understanding the application of the court's decision can help schools interpret and apply their legal and ethical obligations within a human rights framework (Meyer 2007).

The judge writing the opinion, Justice Levine, addressed the first question of who is protected by human rights codes by establishing the purpose of such codes in Canada. Justice Levine asserted that human rights codes must have a "broad approach" in application to best achieve the goals of such legislation (School District No. 44 [North Vancouver] v. Jubran 2005, para. 29). In her analysis of the code's objectives, Justice Levine concluded that, as found in Ontario Human Rights Commission v. Simpsons-Sears Ltd., the purposes of human rights legislation were "the removal of discrimination" and to "provide relief for the victims of discrimination." This definition led her to conclude that Jubran's complaint was within the objectives of the code, which aim to "address human dignity and equality and the elimination of persistent patterns of inequality" (School District No. 44 [North Vancouver] v. Jubran 2005, note 10, para 38). This could be interpreted to mean that any behavior that perpetuates patterns of inequality or reinforces discriminatory attitudes in Canadian society, such as repeated incidents of verbal and physical harassment, contravenes the objectives of human rights codes. This reasoning is important for school districts to understand, because it provides a very wide scope of interpretation for human rights protections and es tablishes that any behavior in schools that serves to support or reinforce "persistent patterns of inequality" is subject to complaints under the Code School District No. 44 (North Vancouver) v. Jubran 2005, note 10, para 38.

The second question addressed by this court was the issue of school board liability. The school board argued that it could not be held responsible for the conduct of its students (para. 66). Justice Levine found that al though the school administrators took a disciplinary approach that was "effective vis-`a-vis individual students who were identified and dealt with, it was not effective in reducing the harassment of Mr. Jubran" (para. 68). She cited earlier relevant cases of school board liability and relied heavily on Ross v. New Brunswick School District No. 15 (1996) in her reasoning. In a similar case in Quebec, Kaf'e et Commission des droits de la personne du Qu'ebec c. Commission scolaire Deux-Montagnes (1993), the Tribunal stated,

It is the statutory responsibilities of school boards as well as the compelling state interest in the education of young people (Jones), and the school board's obligation to maintain a nondiscriminatory school environment for students (Ross) which gives rise to the School Board's duty respecting student conduct under the Code.

As a matter of legislation and case authority, there is a legitimate state interest in the education of the young, that stude nts are especially vulnerable, that the School Board may make rules establishing a code of conduct for students attending those sch ools as part of its responsibility to manage those schools. Given this, and the quasi-constitutional nature of the Code, I find that the School Board has the duty to provide students with an educational environment that does not expose them to discriminatory harassment. (emphasis Justice Levine's, para. 115)

In his analysis of this case, Howard (2002) defends the school board and argues that "the Tribunal's analysis does not show that the educators' breach of their duty (let's assume there was breach) caused the harm suffered by Jubran." However, I believe that Justice Levine established this connection. To meet this requirement, Justice Levine supported the Tribunal's reasoning and analysis. She showed causation by asserting that the school board's failure to implement certain policies and procedures "that could reasonably be required to create a discrimination-free school environment" (para. 97) could have provided some relief for Jubran. She referred to the Tribunal's decision listing various potential remedies the school could have provided to meet its duty (para. 89). This section of her decision is important to examine in depth, because it can provide a model for steps that schools must take to meet the standard of accommodating their students to the point of undue hardship. The Tribunal wrote,

Although Handsworth's administration did turn their minds to Mr. Jubran's situation, and discussed different approaches to dealing with it, the School Board did nothing to address the issue of homophobia or homophobic harassment with the students generally, nor did it implement a program designed to address that issue. Neither Mr. Rockwell nor Mr. Shaw were given any guidance or direction by the School Board on how to deal with the situation. I find that the administration had inadequate tools to work with, and insufficient training and education to deal with the harassment. The School Board did not seek assistance from those with particular expertise in the field of harassment, homophobic or otherwise, until Mr. Jubran filed his human rights complaint. By that time, Mr. Jubran was in his fourth year of high school at Handsworth, and the harassment he was experiencing was continuing. 
Despite the efforts of Handsworth's administration in dealing with the harassment, when viewed as a totality, I conclude that the School Board has failed to discharge its burden of demonstrating that it accommodated Mr. Jubran to the point of undue hardship. (emphasis Justice Levine's, paras. 160-161)

In addition to outlining who can claim protections under human rights codes, this case provides clear di rection for teachers and administrators regarding steps to take in dealing with discriminatory expression related to sexual orientation in schools to meet the duty of providing a positive learning environment free of discrimination.

\section{Conclusion}

As the previous cases demonstrate, Canada's human rights protections at both the provincial and federal levels have gone a long way in working to combat discriminatory behaviors toward sexual minorities in school settings. In the discussion of the Jubran case, the detailed explanation of the British Columbia Human Rights codes offers a clear picture of the corrective, rather than punitive, role these codes are designed to play. The purposes of human rights legislation are "the removal of discrimination" and to "provide relief for the victims of discrimination." These codes, along with the Charter, are the reason for the greater legal protections and recognitions afforded to gays, lesbians, and bisexuals in Canadian society. ${ }^{1}$ Unfortunately, there are still regions that are trying to limit the extent of these protections. For example, in 2009, the province of Alberta finally followed up on the Vriend order to write "sexual orientation" into provincial human rights legislation. However, this generally conservative province used the revision of its human rights codes as an opportunity to limit teachers' expression rights around issues of sexual orientation by including a parental opt-out clause. Bill 44 of the Alberta Human Rights Act requires schools to notify parents any time there will be instruction about issues related to sexual orientation, sexuality, or religion, and it allows parents to pull their children out of such structured lessons (Audette 2009). On June 2, 2009, this bill passed the Alberta legislature in spite of major resistance from the Alberta Teachers' Association, Alberta School Boards Association, the College of Alberta School Superintendents, and the Alberta School Councils Association (Audette 2009).

Teachers often find themselves in treacherous waters as they try to find a balance between teaching about democratic principles of equality and respect for diversity and understanding and accommodating the religious views of some students and families in their schools. The Canadian human rights model offers a valuable lens through which to understand these competing claims. The purpose of these codes bears repeating. As the judge in the Jubran case wrote, they are intended to "address human dignity and equality and the elimination of persistent patterns of inequality" (School District No. 44 (North Vancouver) v. Jubran 2005, para. 38). By carefully weighing the actual and potential harms to gay, lesbian, and bisexual students and teachers, which are well-documented (Kosciw, Diaz, and Gretytak 2008; Taylor et al. 2008; Williams et al. 2003; Ferfolja 1998), against the legally justified minimal impairment of some individuals' anti-homosexual religious beliefs, educators can develop approaches for talking about sexual orientation in schools that promote school safety, while allowing space for diverging religious views. This approach applies the human rights model of nondiscrimination and equal access to education that can help guide teachers and administrators as they continue to navigate these controversial and important topics in schools.

\section{Note}

1. It is important to note that transgender and transsexual individuals are not explicitly included in these protections since the terms "gender identity and expression" are not included in most human rights codes.

\section{REFERENCES}

Audette, T. 2009. Alberta passes controversial human rights law. National Post. http://www.nationalpost.com/m/story. html?id=1654445 (accessed February 19, 2010).

Audette, T. 2009. Alberta education groups unite to oppose Bill 44. Edmonton Journal, May 6, 2009. http://www.edmontonjournal.com/ Life/Education+groups+unite+oppose+Bill/1570093/story.html (accessed August 9, 2009).

Canadian Charter of Rights and Freedoms. 1985.

Canadian Children's Rights Council (CRC). n.d. About the U.N. Convention on the Rights of the Child (UNCRC). Canadian CRC. http://www.canadiancrc.com/UN CRC/UN CRC.aspx (accessed August 12, 2009).

Curcio v. Collingswood Board of Education. 2006. U.S. Dist. LESIX 46648. D.N.J.

Eckes, S. E., and M. M. McCarthy. 2008. GLBT teachers: The evolving legal protections. American Educational Research Journal 45(3): 530-54.

Egan v. Canada. 1995. . 2 S.C.R. 513. Original edition, affirming (1993), 103 D.L.R. (4th) 336, 153 N.R. 161 (F.C.A.), affirming (1992) 1 F.C. 687, 87 D.L.R. (4th) 320 (T.D.).

Ferfolja, T. 1998. Australian lesbian teachers-A reflection of homophobic harassment of high school teachers in New South Wales government schools. Gender and Education 10(4): 401-15.

Frye, M. 1983. Oppression. In The politics of reality: Essays in feminist theory, 1-16. Freedom, CA: Crossing Press.

Howard, J. P. 2002. Following-up on Jubran: Boards, bullying, and accountability. Education Canada 42(3): 40-41.

Hurley, M. C. 2005. Sexual orientation and legal rights. Ottawa: Library of Parliament.

Kaf'e et Commission des droits de la personne du Qu'ebec c. Commission Scolaire Deux-Montagens. 1993. 19 C.H.R.R.D/1.

Kempling v. British Columbia College of Teachers. 2004. B.C.D. Civ.

Kempling, C. 2008. An important message from Dr. Chris Kempling. http://www.bcptl.org/rights.htm\#Kempling2008-06 (accessed June 23, 2009).

Kosciw, J., E. Diaz, and E. Gretytak. 2008. 2007 National School Climate Survey: The experiences of lesbian, gay, bisexual, and transgender youth in our nation's schools. New York: Gay, Lesbian, and Straight Education Network.

Lahey, K. A. 1999. Are we 'persons' yet? Law and sexuality in Canada. Toronto: University of Toronto Press. 
Meyer, E. J. 2007. Lessons from Jubran: Reducing school board liability in cases of peer harassment. Proceedings of the 17th Annual Conference of the Canadian Association for the Practical Study of Law in Education. 1: 561-76.

Meyer, E. J., and D. Stader. 2009. Queer youth and the culture wars: From the classroom to the courtroom in Australia, Canada, and the United States. Journal of LGBT Youth 6(2): 135-54.

Morrison v. Board of Education. 1969. 461 P. 2d 375. Cal.

Ontario Human Rights Commission v. Simpsons-Sears Ltd. 2005. 2 S.C.R. 536.

R. v. Oakes. 1986. 1 S.C.R. 103 at 136.

Ross v. New Brunswick School District, No. 15. 1996. No. 15. 1 S.C.R. 825.

School District No. 44 (North Vancouver) v. Jubran. 2005. . B.C.C.A. 201. Original edition, 2005 leave to appeal dismissed (S.C.C.), 2003 BCSC 6 (B.C.S.C.), quashing (2002), 42 C.H.R.R. D/273,2003 BCHRT 10 sub nom Jubran v. North Vancouver School Dist. No. 44.

Taylor, C., T. Peter, K. Schacter, S. Paquin, S. Beldom, Z. Gross, and T. L. McMinn. 2008. Youth speak up about homophobia and transphobia: The First National Climate Survey on Homophobia in Canadian Schools, phase one report. Toronto, ON: Egale Canada Human Rights Trust.

Trinity Western University v. British Columbia College of Teachers. 2001. S.C.R. 772.

United Nations. 1948. Universal declaration of human rights. United Nations.

United Nations Children's Fund (UNICEF). 2009a. Convention on the rights of the child. UNICEF. http://www2.ohchr.org/english/law/ crc.htm (accessed August 12, 2009).

-.--. 2009b. The human rights framework. UNICEF. http://www. unicef.org/crc/index framework.html (accessed August 12, 2009).

Vriend v. Alberta. 1998. 1 S.C.R. 493. Original edition, reversing (1996), 132 D.L.R. (4th) 595, 34 C.R.R. 2 d 243 (Alta C.A.), reversing (1995), 23 C.R.R. (2d) D1 (Alta Q.B.).

Watkinson, A. 1999. Education, student rights and the charter. Saskatoon, SK: Purich.

White, H. 2008. Chris Kempling to quit BC teachers' college after years of harassment for Christian beliefs. LifesiteNews.com. http://www.bcptl.org/rights.htm\#Kempling2008-06 (accessed August 10, 2009).

Williams, J. 2005. Homophobic bullying in school. A. Jubran, ed. Vancouver Cooperative Radio. http://www.rabble.ca/rpn/rey/45192 (accessed August 10, 2009).

Williams, T., J. Connolly, D. Pepler, and W. Craig. 2003. Questioning and sexual minority adolescents: High school experiences of bullying, sexual harassment and physical abuse. Canadian Journal of Community Mental Health 22(2): 47-58. 